\title{
THE "BURDEN" OF KNOWLEDGE: UNWANTED KNOWLEDGE IN MANAGEMENT - THE PERSPECTIVE OF INDIVIDUAL AND ORGANIZATIONAL LEVEL
}

\author{
Marta Moczulska \\ University of Zielona Góra, Zielona Góra, Poland \\ e-mail:m.moczulska@wez.uz.zgora.pl \\ Renata Winkler \\ Cracow University of Economics, Cracow, Poland \\ e-mail: winkler@uek.krakow.pl \\ (C) 2018 Marta Moczulska, Renata Winkler \\ This is an open access article distributed under the Creative Commons Attribution-NonCommercial-NoDerivs license \\ (http://creativecommons.org/licenses/by-nc-nd/3.0/) \\ DOI: $10.15611 / \mathrm{ms} .2018 .1 .05$ \\ JEL Classification: D83
}

\begin{abstract}
The purpose of this paper is to consider issues related to the little-known problem in the area of knowledge management. This problem is the "burden" of knowledge (unwanted knowledge). In pursuing the aim of this paper, the following issues were discussed: the issue of action, knowledge in the organization in the context of cooperation and the effectiveness of actions.
\end{abstract}

Keywords: knowledge management, the "burden" of knowledge, effectiveness of actions, employee's engagement.

\section{Introduction}

Contemporary organizations operate under conditions of a high level of uncertainty, and changes constitute an integral element of their operations. The scope and dynamics of transformations of the organizations' contemporary environment have resulted in the fact that they do not rely only on the maximization of the "usability" of the possessed resources and the optimization of the dynamics of human behavior as well as on promoting and molding the desired shape of organizational culture. Organizations continuously aim at creating new models of thinking, focus on the learning process and constantly adjust the undertaken assumptions and plans. Knowledge was granted the status of a strategic resource in the context of these needs of the organization, among others. Controlling knowledge plays a key role in building a long-term competitive advantage. Consequently, publications with regard to management sciences have included analyses of issues related to knowledge management since the 1980s. The purpose of this study is to examine issues related to a topic in the sphere of knowledge management which was previously scarcely described, namely the "burden" of knowledge (unwanted knowledge) Undertaking this issue in the context of the need for cooperation between employees existing in organizations seems particularly interesting. This need exists due to the degree of the complexity of the organization's objectives which remain unachievable in individual actions. Therefore, this study, apart from issues related to knowledge, will also discuss issues related to acting and the effectiveness of actions. The attention was focused on the relationship between individual and organizational "burden" of knowledge and the awareness and work engagement as well as their impact on the effectiveness of human resources. 


\section{Acting - outline of the theory}

T. Pszczołowski [1978, p. 56] determines acting as intentional, conscious and any behavior, where:

1. The purpose is understood widely as the direction of actions (see: [Korzeniowski et al. 1983, p. 43; Szewczuk (ed.) 1998, p. 73].

2. Consciousness should be understood) as performing cognitive control.

3. Freedom applies to one's own autonomy, namely perceiving that one is the initiator (source) of behavior. An initiator who not only assesses the elicited behavior (including its effects/consequences), but also anticipates subsequent actions and is able to change them regardless of whether they are only planned or have already been completed.

A. Słaboń and M. Pacholski [Słaboń, Pacholski 1997, pp. 22, 40] perceive actions as human behavior if and unless the acting entity connects a certain subjective sense to this behavior.

The individual's actions as behavior are thus focused, undertaken intentionally and voluntarily. At the same time, they have (as J. Seifert [1984, pp. 14-16] states) two typical features:

1. Universality, which means that actions are not only focused towards the environment affecting the reality beyond the acting person, but also "transforms 1 " the acting entity.

2. Internal attitude towards a given state of affairs, which is a response to its significance (meaning), expressed in the decision to act, and then in the willingness to implement this state of affairs which involves the physical/spiritual performance of the action. In order for an action to take place, it is necessary to assume its actual or probable implementation (action or omission ${ }^{2}$ ).

In most cases, actions also involve making decisions and thus are based on the available knowledge. They may also require its acquisition or deepening (namely - in practical terms: learning). Taking into account the categories of actions, we may distinguish such actions as [Kwaśniewicz et al. (eds) 1998, pp. 159-160]:

- $\quad$ traditional and habits, namely customary, mechanical (automatic) to a significant extent, not requiring reflections;

- emotional, namely made in affection (spontaneous), without thinking, without paying attention to consequences;
- rational in an instrumental sense, related to a choice of actions which, according to knowledge, will make it possible to achieve the purpose rather quickly and with low outlays and costs;

- intentionally rational, which means a conscious formulation of the purpose and the choice of means for its implementation.

With regard to organizations, it is worth differentiating between actions conducted individually (namely independently by the employee) as well as collectively (which means performing actions by more than one person, e.g. in a team). Collective actions involve various degrees of interdependence. Conditional collective actions (defined as cooperation) may be favorable to improve the processes related to the functioning of the organization, developing the company or improving the quality of the offered services and products. This type of actions, in particular, requires the transfer of knowledge and creating knowledge. The effectiveness of this type of employee's actions depends both on assimilating knowledge ${ }^{3}$ and on the extent to which this assimilated knowledge is used in the organization. At the same time, it is worth emphasizing once more that undertaking a specific action (or cooperate) by the employee also affects him/her too (as was stated by J. Seifert quoted above, the entity is "transformed"). The person implementing the action is also affected by the actions of other persons implemented separately or as part of their cooperation. In other words, the employee's action (focused according to the sense conferred by the person undertaking this action - the co-workers) is each time (unless it is implemented in isolation) referred to the behavior of other persons in its course. This is a situation in which the following may be indicated, with regard to the acting of organization member (see: [Covey 2001, p. 87]): (1) the area subject to its direct control (its own behavior), (2) the area subject to intermediate control - namely such an area in which the worker to a certain extent may influence the behavior of other employees, as well as (3) the area which is not controlled by him/ her. The arrangement of these three areas forms a framework for actions (which may be identified using the acronym $\mathrm{CIA}^{4}$ ). Particular significance is played by the factor of interpersonal relations as part of the cooperation in the field of influence. Therefore, the scope of intermediate control from the entity will often depend on the participant's individual social

\footnotetext{
${ }^{1}$ Namely it affects the entity performing the actions.

${ }^{2} \mathrm{~S}$. Galata [2006] also states that actions may consist in performing or resigning from something and, for this reason, according to the author, it is granted only to individuals with awareness.

${ }^{3}$ Namely cognition, understanding and the ability to use it, which involves learning.

${ }^{4}$ Control, Influence, Acceptance.
} 
competences (such as: the ability to recognize the emotional states of oneself and others; the ability to communicate) as well as on factors determining the shape of interactions (for instance, on the sense of justice, the level of trust between participants of the interaction), i.e. conditions created in the organization for both individual and collective activity.

\section{Knowledge in an organization in the context of cooperation}

Knowledge (regardless of how we will try to define $i t^{5}$ ) does not have an impersonal nature. Only people are the medium for knowledge and its final holder, and knowledge - as "adherent" to man - is unique. Knowledge is related to the ability to use information, to learn and to gain experience in interpreting information as well as determining which pieces of information are necessary and what is their usefulness in making specific decisions. As is proven by A. Toffler and H. Toffler [2006]:

1. Knowledge is intangible. We may use knowledge but we cannot touch it.

2. Knowledge is non-linear. There is no one clear correlation between the volume of collected (owned, at the disposal/acquired) resources of knowledge, and the benefits which result from this fact.

3. Knowledge is inherently non-rival - people are not able to "deplete" the knowledge resource. The more people use a given knowledge resource, the greater the likelihood that new knowledge will be created as a result. Apart from a situation in which the pool of knowledge consists of patents, having a given knowledge is not equivalent to having it exclusively.

4. Knowledge is relational. A "piece" of knowledge has meaning only with regard to other "pieces" of knowledge which contribute to the creation of context and the possibility to use knowledge

5. Knowledge mates with other knowledge. The more possibilities to use the combinations of various kinds of knowledge, the greater the extent in which we are dealing with the combination (integration) of knowledge.

6. Knowledge is more portable than any other product. Knowledge may be transferred by the individual to many people at the same time

7. Knowledge can be stored in smaller and smaller devices. Due to the technological progress, better and better software and data carriers, trillions of gigabytes may be stored on small devices.

8. Knowledge can be compressed into symbols or abstractions.
9. Knowledge is hard to bottle up. Knowledge is permanently spreading.

10. Knowledge can be explicit or implicit, expressed or not expressed.

Drawing the attention to action (cooperation), it is worth referring to certain kinds/types of knowledge. The main and important division is the division into open and hidden knowledge (more: [Nonaka, Takeuchi 2000]). The former is easy to describe and document, and the latter - although it is used in daily activities, it is difficult to articulate expressly.

In turn, C. Savage distinguishes the following types of knowledge (as in [Skyme 1999, p. 46]):

- to know how - this knowledge refers to the knowledge of procedures of actions, qualifications,

- to know who - knowledge the essence of which is the knowledge of people who have the necessary knowledge (as a result, they may help find an answer to a question or perform a task).

- to know what - related to the structure of phenomena,

- to know why - knowledge making it possible to perform a relevant interpretation of possessed information and understand the wider context of actions,

- to know when - knowledge related to a temporary, rhythmic sense of actions,

- to know where - knowledge related to where it is best to perform the action.

In turn, taking into account the criterion of diversity, the following are distinguished [Flakiewicz 2002, p. 36]:

- certain knowledge - based on facts and proven laws,

- uncertain knowledge - only partially confirmed with facts and laws,

- hypothetical knowledge - based on presumptions,

- ignorance - total lack of knowledge in a given area.

Finally, referring to cooperation, the division into individual and collective knowledge should be mentioned (in which the former is adherent to the individual, and the latter is created during teamwork, joint problem solving and exceeds the sum of the individual resources of knowledge of people involved in cooperation).

The fundamental processes related to knowledge include generating knowledge and transferring it. Generating, namely creating new knowledge, includes also developing knowledge and multiplying the already owned resources. Generating knowledge requires teamwork in most cases. The transfered

\footnotetext{
${ }^{5}$ As a state of mind, an object, a process, a set of conditions for access to information, or an ability.
} 
knowledge, in turn, means any action as part of which knowledge owned by the individual is disclosed to other persons ${ }^{6}$. At the same time, it should be emphasized that this process is not limited solely to the relocation of a given resource of knowledge it also includes the modification of the transferred resource of knowledge for its adaptation to be used in a different context [Kumar, Ganesh 2009, p. 163]. A successful transfer of knowledge means such a message which, as a result, makes it possible to acquire the accumulation and assimilation of new knowledge. Authors such as Ch. Liyanage, T. Elhag, T. Ballal and Q. Li [2009, p. 125] emphasize the fact that the transfer of knowledge very often ends with failure when parties participating in it do not manifest the willingness to share knowledge for various reasons ${ }^{7}$. Furthermore, also in the case when both sides are willing to share knowledge, the transfer may end with failure due to certain internal characteristics of the entities participating in this process (limited ability to absorb, assimilate and use knowledge). In the opinion of these authors, the transfer of knowledge needs a certain form of participation from both the source of knowledge and the recipient of this knowledge, as well as the development of a relation between the source and the recipient (or the emergence of cooperation between them).

\section{Effectiveness of actions}

The effectiveness of actions does not involve the category of effectiveness of work, but the effectiveness of human resources management. This, in turn, is not derived from the "objective quality" of employees, but is based on the full use of the potential of the organization's members. This requires obtaining their engagement. As is known, employee's engagement manifests itself in undertaken effort (energy) with which their action is performed [Smythe 2009, pp. 16-17]. Therefore the achieved results depend on the level and intensity of engagement. According to R.T. Mowday et al. (quote from: [Bugdol 2006, p. 85]), the growth in the effectiveness of undertaken actions, the creation of added value is fostered by the employee's engagement which results, first of all, from the strong faith in the organization, the acceptance of its objectives and the belief that it is worth doing something and, second of all, it causes concern for the future of the organization as well as the willingness to affect its functioning ${ }^{8}$. It is necessary to point out that the intensity of engagement is a kind of assessment from the employee regarding work, the organization and co-workers [Sharma, Anupama 2010]. As stated by K. Trus ${ }^{9}$ [quoted from: Kular et al. 2008], this is, on the one hand, based on the knowledge of a member of the organization regarding issues related to this assessment and on the other hand - on feelings associated with them. It may thus be stated that the engagement (effort) of an employee is the consequence of his/her opinions and emotions.

Taking into account the fact that:

1. Employees take into account [Saks 2006; Robinson et al. 2004]:

- the nature of work, including the perception of its importance, difficulties (whether it is a challenge and fosters development) as well as the autonomy in completion,

- relations with their superiors and co-workers which involve the perception of the authenticity and credibility of their behavior, openness to others expressed, for instance, in listening, communicating,

- the principles and rules binding in the organization related to: the remuneration system, the promotion system or the distribution of resources;

2. Engagement is based on fulfilling such needs as [Ayers 2009, pp. 010-011] the feeling of meaning, exercising influence, development, respect and success, it may be said that communication openness and mutual trust also prove to be critical for the intensity of engagement to a significant degree. The length of the communication route is also significant (namely the degree to which communication is direct: the route for transferring messages should be as short as possible), the content transferred during communication (quantity and quality of content, e.g. their usefulness, validity, relevance, completeness, accuracy, credibility, understandability, unambiguity, type of property), the adjustment of content and the method of message to the recipient.

Meanwhile, E.W. Morrison and F.J. Milliken [2003] indicate a collective phenomenon - the silence of employees. According to C. Pinder and H. Harlos (quote from: [Van Dyne et al. 2003]), this is the lack of

\footnotetext{
${ }^{6}$ According to the processes of knowledge conversion.

${ }^{7}$ For instance, due to confidentiality, cultural barriers or the fear of losing competitive advantage.

${ }^{8}$ R.T. Mowday, L.W. Porter and R.M. Steers (quoted from: [Bugdol 2006, p. 85]) define it as effective, also listing sustained commitment which does not result in added value although it means a well-performed work.

${ }^{9}$ These are the so-called dimensions of engagement - accordingly: cognitive (opinion), emotional (feelings) as well as physical (effort).
} 
behavioral, cognitive and/or affective responses from employees, related to the assessment of the situation in the organization. The topics covered by the issue of silence include: the competences of superiors, coworkers, problems related to organizational processes as well as the company's growth, including changes. These may affect the engagement of employees. F. Bowen and K. Blackmon [2003] as well as S. Piderit and S. Ashford [2003] also indicate personnel issues. Although they do not always affect the work or the functioning of the organization, they may affect interpersonal relations and as such be the reason for silence. They may also be connected to suppressed issues related to the company and, as such, "require" the continued abandonment of making statements.

It is worth noting that the silence of employees does not only apply to passive people. As indicated by L. Van Dyne, S. Ang and I.C. Botero [2003], passive employees are characterized by the so-called consenting silence, while active employees - prosocial and/or defensive. It should be added that the authors examine both the silence of employees as well as expressing their opinions, treating them as supplementary rather than contradictory issues. They show the various consequences of behaviors. In the case of the first type of silence, the abandonment of speaking is based on perceiving the lack of possibilities to introduce changes or the positive consequences of articulating one's opinions and leads to lowering engagement, often manifested in neglecting one's duties, and even idleness. Speaking in this situation may be the Abilene paradox ${ }^{10}$ or express pluralistic ignorance $^{11}$ which, in turn, cripples the action. In the second case, the source is relations with others. That is why it may be indicated that silence, based on the reluctance to endanger cooperation, requires effort and may create the individual's additional internal tension - despite the intention to reduce the level of interpersonal hazard. Speaking, consisting in presenting ideas and solutions improving actions and processes, may prevent the appearance of this tension and contribute to an improvement in the functioning of the organization. In the third case, while silence results from the fear of the consequences of speaking - expressing one's opinions, suggesting changes, the risk of being seen as the person responsible for the problem ${ }^{12}$, speaking is an attempt to redirect attention, accuse others, manipulate information by using such techniques as, among others, interrupting the communication, diversions, exaggerating, controlling information. This may destroy interpersonal relations, deteriorate the atmosphere in the team.

The most common effects of silence from the organization's members are psychosocial effects (see: [Morrison, Milliken 2003; Bowen, Blackmon 2003; Van Dyne et al. 2003]): stress, lack of satisfaction from work, cynicism which reduce the engagement in the functioning of the organization and, at the same time, raise the number of misunderstandings among employees, disturb learning in the organization and cause, among others, a decrease in effectiveness and a reduction in the company's turnover.

Factors determining silence include [Miliken et al. 2003; Bowen, Blackmon 2003]:

- individual characteristics of the individual, including the feeling of one's own value, the location of control as well as the degree of selfcontrol, as well as the lack of professional experience and/or a weak position in the organization understood as the importance of one's position and the function in the company,

- relations with the superior: an autocratic management style as well as perceiving the superior as a closed person not supporting the actions of others,

- other members of the organization, co-workers by expressing opinions ${ }^{13}$,

- organizational factors such as: excessively expanded vertical organizational structure (the socalled slender), linear; organizational culture which is not beneficial for free speaking.

\section{Ignored problem: unwanted knowledge}

The effectiveness of actions depends to a significant degree on the acting entity. As it was determined action is an intentional, conscious and any behavior undertaken when the individual connects a specific subjective sense to this behavior. The effect of action essentially depends on the employee's engagement as well as awareness (Figure 1). Awareness is understood as a subjective image of the reality

\footnotetext{
${ }^{10}$ This means that the individual agrees to make such a decision in the group which all the individuals separately believe to be bad because he/she thinks that all others want this.

${ }^{11}$ Namely the uncertainty about the opinions of others, the fear that we are the only person to have a different opinion.

${ }^{12}$ As in F. Milliken, E. Morrison and P. Hewlin [2003], an employee may be regarded as a person who conveys incorrect messages, creates problems or criticizes the superior/the management.

${ }^{13}$ As F. Bowen and K. Blackmon [2003] point out, employees afraid of social isolation will speak when they believe that their opinion is not isolated and will be silent when they believe that their different opinion will not be supported and/or will not be analyzed.
} 
held by the individual (subjective awareness of the interna $1^{14}$ and external situation of the acting entity). This image depends on the perception and the assessment of a given person. It is created on the basis of the available and acquired resources of knowledge about everything that applies to/is connected with the undertaken action, and each new fact ("piece of knowledge") gains a specific meaning in the context of the resources of knowledge already owned by the individual). This subjective image is significant for assessments and opinions (internal attitudes towards the perceived state of affairs) formulated by the entity which are the basis for a decision on undertaking an action, the intensity of engagement as well as the actual effort ${ }^{15}$. Therefore, this image is of great importance for the effectiveness of actions because it shapes the belief (in the emotional or instrumental aspect) that it is worth (or not worth) doing something. Furthermore, what the entity knows (or what it learns) determines its belief about what is actually subject to its direct or indirect control, and what is the area which cannot be controlled by it.

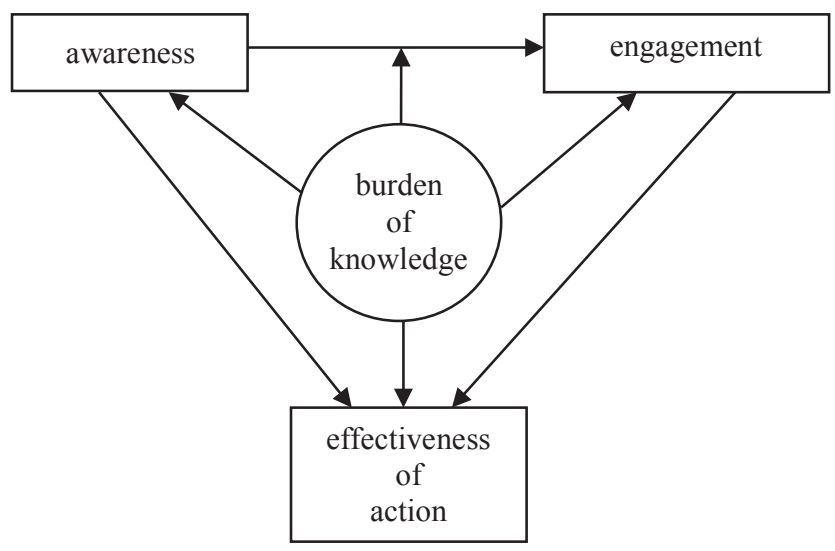

Fig. 1. Effectiveness of actions vs. awareness and engagement

Source: own study.

At the same time it should be emphasized that this subjective image of the reality is created not only on the basis of acquired/possessed "certain" knowledge, but also acquired/possessed resources of uncertain" and "hypothetical" knowledge - as well as on the basis of the informed scope of one's own "ignorance".
If knowledge is important for engagement, it seems reasonable to care not only for its quality but also for its type and scope. The literature on the subject draws attention to the following issues: selecting information (decisions on which pieces of information are necessary from the perspective of the organization's functioning), transfer of knowledge, shaping an atmosphere favoring cooperation. Receiving unwanted pieces of information by employees, namely the ones the possession of which inhibits the functioning of the individual, or the individual decides that it would be better not to know them after hearing them, poses a risk for effective actions and cooperation. We may refer to the burden of knowledge ${ }^{16}$. The consequence of such a burden may be a change to the image of the reality available to the individual which will cause not only a cognitive dissonance of the acting person, but will negatively "transform" the person, questioning the sense of meaning of the action (or the sense of meaning in the effort) and thus will cause a decrease in engagement, finally reducing the effectiveness of actions. For instance, a resource of knowledge ${ }^{17}$ regarding issues which the individual cannot control and which, in perspective, may endanger (although they do need to do so) the execution of objectives designated by the individual, may substantially affect the shaping of the sense of meaning in undertaking actions and thus the engagement in these actions and, as a result, their effectiveness.

It is important to remember that each employee may consider something else as unwanted knowledge. At the same time, it should be added that so far we have examined a situation in which new knowledge, as knowledge unwanted by the individual, became a burden for the individual thus changing the image of the reality, affecting its actions and negatively affecting the functioning of the organization (2nd quarter). However, new pieces of knowledge that the individual receives (acquires) may prove unwanted knowledge (the burden) from the point of view of the organization (Figure 2). This means that acquired knowledge will be perceived by the individual as favorable but, at the same time - causing a change to the image of its reality and then a decrease in engagement - will constitute unwanted knowledge from the point

\footnotetext{
${ }^{14}$ As one's own thinking processes.

${ }^{15}$ For instance, due to the performed assessment whether and to what extent it is worth trusting, the assessment of the level of justice, etc.

${ }^{16}$ It is important to emphasize that there is a small number of available articles on this subject. The authors conducted comprehensive review of the scientific literature using EDS Multi search engine (EBSCO Discovery Solution). In accordance with the criteria set out for this kind of research (Withe, Schmidt, 2005), 254 publications have been found with titles containing words "burden of knowledge". In the next step the search results has been narrowed down to scientific articles (110), reviews (86). Finally, only three articles were found as relevant to the researched subject (management related). Most of the publications were medicine-related. Similar results were obtained while checking occurrence of "unwanted knowledge" words in publications titles.

${ }^{17}$ This resource may be a type of "uncertain" or "hypothetical" knowledge.
} 


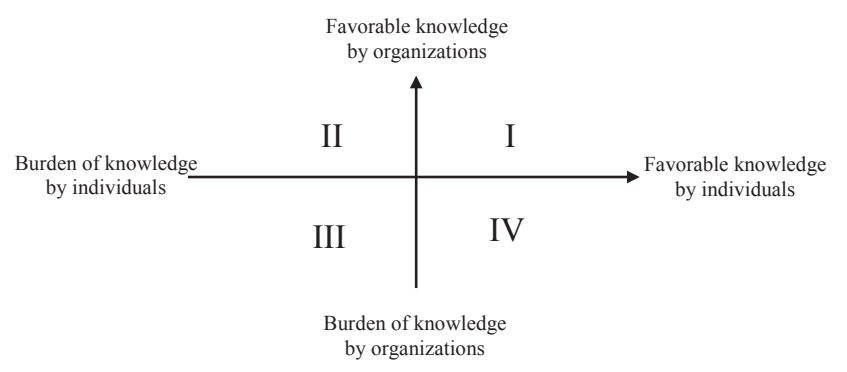

Fig. 2. Favorable knowledge vs the burden of knowledge Source: own study.

of view of the organization (4th quarter). Of course, situations in which knowledge becomes a burden for both the individual and the organization (3rd quarter) or is favorable from both perspectives (1st quarter) are also possible. It is important to remember that each employee may consider something else as unwanted knowledge. At the same time, it should be added that so far we have examined a situation in which new knowledge, as knowledge unwanted by the individual, became a burden for the individual thus changing the image of the reality, affecting its actions and negatively affecting the functioning of the organization (2nd quarter). However, new pieces of knowledge that the individual receives (acquires) may prove unwanted knowledge (the burden) from the point of view of the organization (Figure 2). This means that acquired knowledge will be perceived by the individual as favorable but, at the same time causing a change to the image of its reality and then a decrease in engagement - will constitute unwanted knowledge from the point of view of the organization (4th quarter). Of course, situations in which knowledge becomes a burden for both the individual and the organization (3rd quarter) or is favorable from both perspectives (1st quarter) are also possible. While the 1 st quarter corresponds to the "ideal" situation, the 3rd quarter depicts an unwanted situation which - although it seems that it requires an intervention - may be "easier" to solve. Questions regarding the possibility of conduct in the case of differences in the assessments (different perception) of knowledge possessed by the individual and the organization come into being. Taking into account the issue of the silence of employees, it may be assumed that these situations may ultimately be unfavorable also for the party which considers them favorable. However, this requires a detailed analysis of the possible behavior from employees and its effects.

\section{Conclusion}

The paper deals with the issue of "burden of knowledge". It refers to the situation where employees receive unwanted (undesirable) information. Unwanted (undesirable) in this way, that after hearing them the receiver finds that it would be better not to know them. Such unwanted knowledge interferes with the functioning of these persons. It becomes a threat to the engagement and effectiveness for both the individual (on the part of that person) and the collective, resulting in a threat for their cooperation (indirectly a threat to the functioning of the organization). The importance of perception needs to be emphasized. Every employee is the "holder" of the knowledge as well as its interpreter.

Therefore, also in this article, the diagram illustrates the relationship between the effectiveness and the awareness together with engagement considering both the perspective of the employee as well as the perspective of the whole organization.

Thus, it seems that further analyzes should be focused not only on the verification of the model's assumptions, but also on the issues related to it. For example, the behavior of employees if the knowledge deemed to be favorable to the employee and at the same time it can be the burden for the organization. This will allow for the future modeling of the burden of knowledge as part of the interaction between employee engagement and awareness and the effectiveness of the organization's actions.

\section{Bibliography}

Ayers K., 2009, Why engagement is not enough, Training \& Development in Australia, April, pp. 010-011.

Bowen F., Blackmon K., 2003, Spirals of silence: The dynamic effects of diversity on organizational voice, Journal of Management Studies, vol. 40(6), pp. 1393-1476.

Bugdol M., 2006, Wartości organizacyjne, Wydawnictwo Uniwersytetu Jagiellońskiego, Kraków.

Covey S., 2001, 7 nawyków skutecznego działania, Bertelsman Media Sp. Z o.o. Diogenes, Warszawa.

Flakiewicz W., 2002, Systemy informacyjne w zarządzaniu. Uwarunkowania, technologie, rodzaje, Wydawnictwo C.H.Beck, Warszawa.

Galata S., 2006, Uwarunkowania działań zespołowych: temperament, inteligencja, intuicja, konflikt, Krakowskie Towarzystwo Edukacyjne - Oficyna Wydawnicza AFM, Kraków.

Korzeniowski K., Zieliński R., Daniecki W., 1983, Podmiotowość jednostki $w$ koncepcjach psychologicznych $i$ organizacyjnych, Zakład Narodowy im. Ossolińskich, Wrocław.

Kular S., Gatenby M., Rees Ch., Soane M., Truss E., 2008, Employee engagement: a literature review, Working Paper Series, no. 19. 
Kumar J.A., Ganesh L.S., 2009, Research on knowledge transfer in organizations: a morphology, Journal of Knowledge Management, vol. 13(4), pp. 161-174.

Kwaśniewicz W. et al. (eds), 1998, Encyklopedia socjologii, tom 1, Oficyna Naukowa, Warszawa.

Liyanage Ch., Elhag T., Ballal T., Li Q., 2009, Knowledge communication and translation - a knowledge transfer model, Journal of Knowledge Management, vol. 13(3), pp. 118-131.

Milliken F.J., Morrison E., Hewlin P., 2003, An exploratory study of employee silence: Issues that employees don't communicate upward and why, Journal of Management Studies, vol. 40(6), pp. 1453-1476.

Morrison E.W., Milliken F.J., 2003, Guest editor's introduction. Speaking up, remaining silent: The dynamics of voice and silence in organizations, Journal of Management Studies, vol. 40(6), pp. 1353-1358.

Nonaka I., Takeuchi H., 2000, Kreowanie wiedzy w organizacji, Poltex, Warszawa.

Piderit S.K., Ashford S.J., 2003, Breaking silence: tactical choices women managers make in speaking up about gender-equity issues, Journal of Management Studies, vol. 40(6), pp. 1477-1502.

Pszczołowski T., 1978, Mała encyklopedia prakseologii i teorii organizacji; Zakład Prakseologii Instytutu Filozofii i Socjologii PAN w Warszawie, Zakład Narodowy im. Ossolińskich, Wrocław.
Robinson D., Perryman S., Hayday S., 2004, The Drivers of Employee Engagement, Institute for Employment Studies, Brighton.

Saks A.M., 2006, Antecedents and consequences of employee engagement, Journal of Managerial Psychology, Vol. 21 (7), pp. 600-619.

Seifert J., 1984, Istota i motywacja moralnego działania, Wyd. Św. Krzyża, Opole.

Sharma B.R., Anupama R., 2010, Determinants of employee engagement in a private sector organization: an exploratory study, Advances in Management, vol. 3, pp. 52-59.

Skyme D.J., 1999, Knowledge Networking, Creating the Collaboractive Enterprise, Butterworth Heinemann, Oxford.

Słaboń A., Pacholski M., 1997, Stownik pojęć socjologicznych, AE, Kraków.

Smythe J., 2009, CEO - dyrektor do spraw zaangażowania, Kraków.

Szewczuk W. (ed.), 1998, Encyklopedia psychologii, Fundacja Innowacja, Warszawa.

Toffler A., Toffler H., 2006, Revolutionary Wealth: Shaping Tomorrow's Way of Life, Knopf, New York.

Van Dyne L., Ang S., Botero I.C., 2003, Conceptualizing employee silence and employee voice as multidimensional constructs, Journal of Management Studies, vol. 40(6), pp. 1359-1392.

\section{„BALAST” WIEDZY: WIEDZA NIECHCIANA W ZARZĄDZANIU Z PERSPEKTYWY JEDNOSTKI I ORGANIZACJI}

Streszczenie: Celem opracowania jest rozważenie kwestii dotyczących mało dotychczas opisanego zagadnienia, jakim w obszarze zarządzania wiedzą jest „balast” wiedzy (wiedza niechciana). Stąd też w niniejszym artykule, prócz kwestii dotyczących wiedzy, omówiono problematykę związaną z działaniem i efektywnością działania.

Słowa kluczowe: zarządzanie wiedzą, "balast" wiedzy, efektywność działania, zaangażowanie pracowników. 